\title{
Prostate Cancer Clinical Primary Tumor TNM Finding v7
}

National Cancer Institute

\section{Source}

National Cancer Institute. Prostate Cancer Clinical Primary Tumor TNM Finding V7. NCI

Thesaurus. Code C89207.

A clinical finding about one or more characteristics of prostate cancer, following the rules of the TNM AJCC V7 classification system as they pertain to staging of the primary tumor. (from AJCC 7th Ed.) 